\title{
"A REVIEW ON APARAJITA (CLITORIA TERNATEA) WITH SPECIAL REFERENCE TO VISHA CHIKITSA"
}

\section{Savita B. Chougule}

Assist. Prof. Dept. Of Agadtantra

Seth Govindji Raoji Ayurved Mahavidyalaya, Solapur, Maharashtra.

Email id - dr.savita15@gmail.com

\section{ABSTRACT:}

Agadtantra is the sixth branch of ayurveda which mainly deals with agada i.e. the medicine with antipoisonous effects. These antipoisonous drugs are prepared by combination of several drugs. Various medicinal plants are described in ayurveda which are used in the treatment of poisoning (Visha), one of them aparajita. In bhavprakash nighantu an kaiyadev nighantu it is mentioned 'vishapaha' which alleviates toxins. In sushruta samhita it is included in arkadi gana which is also vishapaha i.e. which eliminates poison. Pharmacological activities of aparajita like nephroprotective, diuretic, hepatoprotective, anti inflammatory, antihistaminic are proved. The roots, flowers, seeds and leaves are used for medicinal purpose both internally as well as externally. This review is small attempt to explore its antipoisonous formulations and antipoisonous activity.

KEY WORDS: Aparajita, vishapaha, Antipoisonous formulation (agada).

\section{INTRODUCTION:}

Agadtantra is the sixth branch of ayurveda which mainly deals with agada i.e. the medicine with antipoisonous effects. These antipoisonous drugs are prepared by combination of several drugs. Various medicinal plants are described in ayurveda which are used in the treatment of poisoning (visha), one of them is aparajita. In bhavprakash nighantu and kaiyadev nighantu it is mentioned as 'vishapaha' which alleviates toxins. ${ }^{1,2}$ In ushruta samhita it is included in arkaadi gana which is also vishapaha i.e. which eliminates poison. ${ }^{3}$

Aparajita grows through out india. It is a beautiful looking plant, hence cultivated in gardens. The flowers resemble in shape to cows ear, hence the synonym gokarnika. ${ }^{4}$ Two varities, blue and white flowered are mentioned in ayurvedic texts. The roots, flowers, seeds and leaves are used for medicinal purpose both internally as well as externally. ${ }^{1}$ This review is small attempt to explore its antipoisonous formulations and antipoisonous activity.

\section{MATERIALS AND METHODS :}

All relevant information were collected from ayurveda authentic texts, electronic database search and scientific journals.

\section{Morphology -}




\begin{tabular}{|c|c|}
\hline Sanskrit & 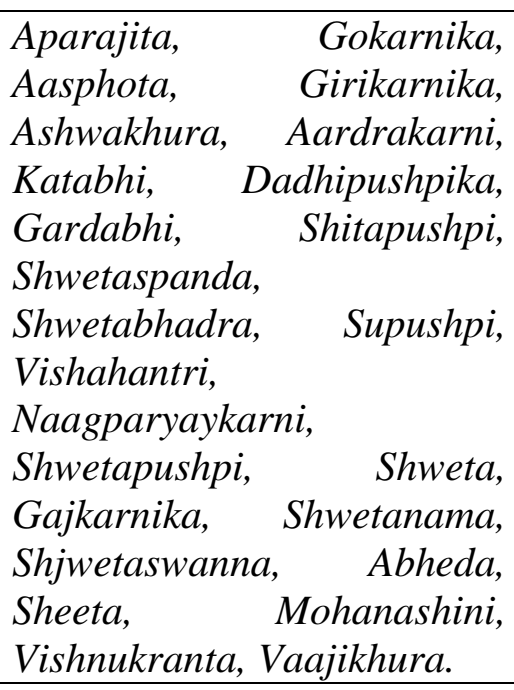 \\
\hline Hindi & Aparajita \\
\hline Bengali & Aparajita \\
\hline Gujrati & Kaaligaranii, Kaalikoyal \\
\hline Tamil & Kaakkanam \\
\hline Telugu & Dinten \\
\hline Kannad & Shankhapushpa \\
\hline Marathi & Gokarna \\
\hline Malayalam & Shankapushpm \\
\hline
\end{tabular}

It is a perennial twining herb having 7 leaflets, which are elliptic and obtuse. Leaves are pinnate 5-9 foliolate. Flowers are showy, blue or white, petals are unequal, style bearded below the stigma. Fruit pods are linera and compressed. The pods are $5-7 \mathrm{~cm}$ long, flat with 6 to 10 seed in each pod. Seeds are 6-10 and black in colour. Plant flowers in rainy season and fruits in winter. ${ }^{5}$

\section{Chemical Constituents $^{6}$ -}

Root - It contain taraxerol and taraxerone.

Seed - It contain cinnamic acid and an anthoxanthin glucoside.
Seed oil - It contain palmitic, stearic, oleic, linoeic and linolenic acids.

Leaves - It contain glycosides of kaempferol and stigmast-4-ene-3, 6-dione.

Flowers - It contain delphinidin - 3, 5 diglucoside.

Table No. 1 Taxonomical Classification of Aparajita (Clitorea ternatea) ${ }^{7}$

\begin{tabular}{|l|l|}
\hline Kingdom & Plantae \\
\hline Order & Fabales \\
\hline Family & Fabaceae \\
\hline Genus & Clitoria \\
\hline Species & C. ternatea \\
\hline Botanical Name & Clitoria ternatea Linn. \\
\hline
\end{tabular}

Table No. 2 Vernacular names of Aparajita (Clitorea ternatea) ${ }^{8}$

able No. 3 Pharmacological Properties ff Aparajita according to Ayurveda'

\begin{tabular}{|l|l|}
\hline Rasa & Tikta, Katu, Kashaya \\
\hline Virya & Shita \\
\hline Vipaka & Katu \\
\hline Guna & Tikshna, Laghu \\
\hline Doshakarma & Tridoshghna \\
\hline
\end{tabular}

\section{Pharmacological activity according to ayurveda -}

It is useful in the treatment of udar, kaphavikar, jwar, mutravikar, galgand, gandmala, shotha, netrarog, unmad, aamavat, kushtha, and visha vikar. ${ }^{1}$

\section{Pharmacological Activity -}

\section{1)Nephroprotective activity -}

It is shown that the administration of ethanol extract of Clitoria ternatea has nephroprotective potential against APAP- 
induced nephrotoxicity. This nephroprotective activity of clitoria ternatea might be due to the synergetic effect of chemical compounds present in them making them good sources for the production of a nephroprotective herbal medicine. ${ }^{10}$

\section{2)Diuretic Activity -}

The powdered form of dried whole root and ethanol extract were evaluated for diuretic activity and only single I.V. dose of extract produce moderate increase in urinary excretion of $\mathrm{Na}, \mathrm{K}$ and decrease in $\mathrm{Cl}$ but no change in urine volume. Also so appreciable effect seen on oral dosing. ${ }^{11}$

\section{3)Anti carcinogenic activity -}

Clitoria ternatea extracts is well correlated with other reports from different plant extracts on cancer suppressing activity or anti carcinogenic activity. ${ }^{12}$

\section{4)Antioxidant activity -}

The plant is a rich source of phytochemicals, with high levels of phenolic compounds and antioxidant activities. ${ }^{13}$

5)Anti- epileptic activity - Methanol extract from the parts of Clitorea ternatea was screened by using pentylenetetrazol (PTZ) and maximum electroshock (MES) - induced seizures in mice at the dose of $100 \mathrm{mg} / \mathrm{kg}$ p.o. CT significantly delayed the onset of convulsions and also delayed the duration of tonic hind limb extension in MES induced convulsions. ${ }^{11}$

\section{6)Anti-microbial Activities -}

The leaf was found to possess powerful antibacterial activity against E. coli and V. cholera known for causing dysentery and
S. aureus, causative agent of fever. Both extracts were shown to be bactericidal in their mode of action. The leaf extract showed stronger antibacterial activity than root extract. ${ }^{11}$

\section{7)Immunomodulatory effects -}

The studies were conducted on oral administration of aqueous extract of Clitoria ternatea to alloxan induced diabetic rats for a duration of 60 days which significantly decreased the serum glucose and cholesterol levels. The total white blood cells, red blood cells, Tlymphocytes and B lymphocytes were significantly increased in treated animals, while monocytes and eosinophils showed an opposite trend. These results further indicate that these plant extracts have immunomodulatary effects that strengthen the immune system. ${ }^{11}$

\section{Anxiolytic activity -}

Alcoholic extract of Clitotrea ternatea orally at a dose of $460 \mathrm{mg} / \mathrm{kg}$ significantly prolonged the time taken to traverse the maze as produced by chlorpromazine in rat demonstrate significant effect on anxiety. ${ }^{14}$

\section{9)Anti inflammatory, analgesic activity} $-$

The anti-inflammatory analgesic from the flowers of Clitotrea ternatea Linn. Showed that it exhibited significant anti inflammatory activity at dose level 200 and $400 \mathrm{mg} / \mathrm{kg}$ body weight. While the analgesic activity was exhibited at the dose level of $400 \mathrm{mg} / \mathrm{kg}$ bodyweight. ${ }^{15}$

\section{0)Hepatoprotective activity -}

The methanol, chloroform and petroleum ether extracts of roots of blue and white flowered varities of clitorea ternatea were 
found to have hepatoprotective property. This was assessed by evaluating their hepatoprotective potential against carbon tetrachloride induced hepatotoxicity in rats. $^{16}$

\section{1)Wound healing activity -}

The effects on wound healing were investigated using excision, incision and dead space models in rats. Seed and root extracts significantly improved wound healing property when administered orally by gavages as well applied topically as ointment which are comparable to that of cotrimoxazole ointment. The finding of this study suggested that plant possesses effects on all three phases of wound healing, inflammatory, proliferative and remodeling phase. ${ }^{17}$

\section{2) Antidiabetic activity -}

The leaf and flower extracts of clitore ternatea have a hypoglycaemic effect. The extracts were effective in regulating the biochemical indices associated with diabetes mellitus. ${ }^{18}$

\section{3)Antihistaminic activity -}

Clitorea ternatea showed antihistaminic activity using clonidine and haloperidol induced catalepsy in mice. ${ }^{19}$

\section{4)Antidepressant, tranquillizing and sedative activity -}

In a study of gross behavioural effect following the administration of an alcoholic extract of clitoria ternatea aerial part in a dose range of $1-2 \mathrm{gm} / \mathrm{kg}$ in mice.The results indicate that like chlorpromazine, it possesses prominent CNS effects characterized by tranquillizing properties such as dose dependent inhibition of alertness, diminution of spontaneous motor activity and increased sedation. ${ }^{20}$

Formulations of aparajita in visha chikitsa -

A) In sthavara and jangam visha chikitsa -

Aparajita is used to preapare yavagu which is used in the treatment of sthavara and jangama visha. ${ }^{21}$

\section{B) In Snake bite -}

1. Juice of shweta aparajita along with valmika mrutika is useful in snake bite. ${ }^{22}$

2. Shweta aparajita is one of the ingredient of agad which is used in darveekar sarpa (hooded snake) bite treatment. $^{23}$

3. Shweta aparajita is one of the ingredient of agad which is used in mandali sarpa bite treatment. $^{24}$

4. Powder of sinduvara root, vacha and aparajita is given with water in the treatment of darveekar snake bite poisoning. $^{25}$

5. Root powder of shweta aparajita and sinduvara along with water is beneficial in darveekar snake bite. ${ }^{26}$

C) In Rat bite -

1. Ghrita prepared with the paste and juice of shweta aparajita is beneficial in rat bite poisoning. $^{27}$

2. Aparajita along with apamarga, danti, langali etc is used in treatment of rat bite. ${ }^{28}$ 
3. Aparajita along with paste of shweta punarnava and honey is useful in the treatment of kapil mooshika (Rat)bite. ${ }^{29}$

\section{D) In Spider bite -}

1. Aparajita along with sinduvara, haridra, sarpgandha, rasna etc. are made into paste and applied in spider poisoning predominant of kapha. ${ }^{30}$

2. Nasal drops prepared from juice of fruit of aparajita is beneficial in spider bite poisoning. ${ }^{31}$

3. Agad prepared from shirish, bakuchi, surala, katabhi, jati, shweta aparajita is beneficial in spider bite poisoning. ${ }^{32}$

\section{E) In insect bite -}

1. Aparajita along with pippal marich, apamarga etc is used for aplication at bite site in bhramar visha. ${ }^{33}$

2. Fume of shweta aparajita, guggula, bhallataka, arjuna etc. destroy serpents, rats, insects and insects of clothing. ${ }^{34}$

\section{F) In fish bite -}

1. Shweta aparajita, shunthi, marich, pippali along with ghrita is used for application in fish bite poisoning. ${ }^{35}$

2. Application of powder of aparajita, bhinda , trikatu along with honey is beneficial in fish bite. ${ }^{36}$

\section{G) In Visha Upadrav ( Complication of poisoning) -}

If there is excessive bleeding due to poisoning, suvarna bhasma with juice or paste of aparajita is used for treatment. ${ }^{37}$

\section{H) In injury caused by weapon with} poison -

Application of kshara prepared with aparajita, mushkaka, somtwaka, manjishta, shirish and grudhranakhi is useful in the treatment of injury caused by weapon with poison. ${ }^{38}$

Table No. 4 Antipoison formulations containing aparajita

\begin{tabular}{|l|l|l|l|}
\hline $\begin{array}{l}\text { Sr. } \\
\text { No. }\end{array}$ & $\begin{array}{l}\text { Anti poisonous } \\
\text { formulation }\end{array}$ & Ingredients & Indication \\
\hline 1. & Mahasugandhi agada & $\begin{array}{l}\text { Shweta aparajita, shirish } \\
\text { pushpa, sinduvar, chandana, } \\
\text { tagar, haridra, daruharidra, } \\
\text { kushtha etc. }\end{array}$ & $\begin{array}{l}\text { It destroys poison of king of } \\
\text { snake even of vasuki } \\
\text { (Celestial serpent). }\end{array}$ \\
\hline 2. & $\begin{array}{l}\text { Amruta ghrita } \\
\text { (Sushruta samhita) }\end{array}$ & $\begin{array}{l}\text { Seeds of apamarga and shirish, } \\
\text { shweta and neela aparajita, } \\
\text { kakmachi, cow urine. }\end{array}$ & $\begin{array}{l}\text { It is best to mitigate poison } \\
\text { and it restores even a dead } \\
\text { man to life. }\end{array}$ \\
\hline 3. & Meghnaad agad & $\begin{array}{l}\text { Tanduliyaka, kashmarya, } \\
\text { kinihi, aparajita, matulunga, } \\
\text { sharkara, sinduvara. }\end{array}$ & $\begin{array}{l}\text { It is beneficial in the } \\
\text { treatment of darveekara and } \\
\text { rajimana } \text { snake bite. }\end{array}$ \\
\hline 4. & Yapana agad & Shweta aparajita, chandan, & It restores the life of the \\
\hline
\end{tabular}




\begin{tabular}{|c|c|c|c|}
\hline & & $\begin{array}{l}\text { valaka, musta, dhymaka, } \\
\text { katuka, dadima, kumkuma, } \\
\text { shunthi etc. }\end{array}$ & $\begin{array}{l}\text { person who is unconscious } \\
\text { by the effect of poison. }{ }^{42}\end{array}$ \\
\hline 5. & Suryodaya agad & $\begin{array}{l}\text { Shweta aparajita, shriveshtaka, } \\
\text { haridra, daruharidra, } \\
\text { kanchanar, manshila, pippali, } \\
\text { patala, manjishta etc. }\end{array}$ & $\begin{array}{l}\text { It destroys effect of poison } \\
\text { just as the sunrise dispels } \\
\text { darkness. }\end{array}$ \\
\hline 6. & Lodhradi agad & $\begin{array}{ll}\text { Lodhra, shweta } & \text { aparajita, } \\
\text { shirishpushpa, } & \text { harenuka, } \\
\text { marich, vacha etc. } & \\
\end{array}$ & $\begin{array}{l}\text { It destroys the poison of } \\
\text { snakes, rats, wasp, jackal, } \\
\text { dog etc. }{ }^{44}\end{array}$ \\
\hline 7. & Rushabhakaadi agad & $\begin{array}{l}\text { Rushabhaka,jeevaka, bharangi, } \\
\text { madhuka, shweta aparajita etc. }\end{array}$ & $\begin{array}{l}\text { It is useful in treatment of } \\
\text { complications of poisonng. } \\
\text { e.g. Dyspnoea, fever etc. }{ }^{45}\end{array}$ \\
\hline 8. & Param agad & $\begin{array}{l}\text { Vacha, vanshatwaka, patha, } \\
\text { nata, shirish, aparajita etc. }\end{array}$ & $\begin{array}{l}\text { It is useful in the treatment } \\
\text { of insect bite. e.g. } \\
\text { vishwambhara bite }{ }^{46}\end{array}$ \\
\hline 9. & $\begin{array}{l}\text { Amrita ghrita } \\
\text { (Charaka samhita) }\end{array}$ & $\begin{array}{l}\text { Shweta aparajita, shirish twak, } \\
\text { trikatu, chandan, sariva, patala } \\
\text { etc. }\end{array}$ & $\begin{array}{l}\text { It is useful in all types of } \\
\text { poisoning. It revives the } \\
\text { persons almost dead due to } \\
\text { poisoning and hanging. }\end{array}$ \\
\hline
\end{tabular}

\section{DISCUSSION -}

In bhavprakash nighantu, kaiyade nighantu and sushruta samhita it mentioned that aparajita is 'vishapaha' i.e. which eliminates poison. After getting entered into the body poison, vitiates all the tridosha. ${ }^{48}$ According to ayurvedic text, action of aparajita is tridoshghna. Hence it is effective in the treatment of poisoning.

Pharmacological activities of aparajita like nephroprotective, diuretic, hepatoprotective, anti inflammatory, antihistaminic are proved. Aparajita can be used in the treatment of nephrotoxic poisons (lead, mercury etc.) and hepatotoxic poisons (paracetamol, carbon tetrachloride etc.). Due to its diuretic activity it helps in the elimination of poison from the body.

In ayurvedic texts many formulatios of aparajita are described which are beneficial in the treatment of snake bite, spider bite, rat bite, insect bite, fish bite tc. Aparajita is the ingredient of various antipoison formulations (agada) like mahasugandhi agad, amruta ghrita, meghnaad agad, yapana agad, suryoday agad, lodhradi agad, rushabhakaadi agad, param agad, amruta ghrita.

\section{CONCLUSION -}

In ayurvedic texts nine antipoisonous formulation ( agada) containing aparajita are described. It can be concluded that aparajita is beneficial in the treatment of snake bite, spider bite, rat bite, insect bite, fish bite.

\section{REFERENCES -}

1. Dr. K.C. Chunekar, Bhavprakasha Nighantu of Shri Bhavmishra, Chaukhambha Bharati Academy, 
Reprint 2006, Guduchadi varga, pg.no.342, 343.

2. Priyavat Sharma, kaiyadev nighantu, chaukhambha orientalia Varanasi, first edition, Aushadhi varga, verse 10781080, pg. no. 199.

3. Dr.Ambikadatta shastri, Sushruta samhita, Poorvardha, Reprint 2012, Chaukhambha Sanskrit Sansthan, Varanasi, Sutrasthan, chapter 38, Verse 16, pg.no.142.

4. Dr. Prakash Paranjpe, Indian medicinal plants, Chaukhambha Sanskrit pratishthan, Delhi, first edition Reprint 2005, pg.no.14

5. Bakhtiar Lijon, Nigar Sultana Meghla, Eleas Jahedi, Abdur rahman, Ismail Hossain, Phytochemistry and pharmacological activities of clitoria ternatea, International Journal of Natural and Social Sciences, 2017 , 4(1), pg. 2

6. Dr. J.L.N. Sastry, Dravyaguna vidyan Study of the essential medicinal plants in Ayurveda, Chaukhambha orientalia, pg.no.149-151.

7. Chakraborthy GS, Kumar V, Gupta S, Kumar A, Gautam N, Kumari L, Phytochemical and pharmacological aspects of clitoria ternatea - A Review, JAPSR, 1(2), pg. 3 and 4.

8. Vd. Vishnu Gogate, Dravyagunvidyan, Vaidyamitra publication, first edition, pg.no. 235

9. Dr. Deshpande, Dr.Jawalgekar, Dravyaguna vidyan, Anamol prakashan, pune, Reprint 2007, Aushadhi vanaspati, Part II, Pg.No. 411.

10. K. Sarumathy, M.S. Dhana Rajan, T.Vijay, J.Jayakanthi, Evaluation of phytoconstituents, nephroprotective and antioxidant activities of Clitoria ternatea, Journal of Applied
Pharmaceutical Sciences 01 (05), 2011, 164-172.

11. Girish Kumar Gupta, Jagbir Chahal, Manisha Bhatia, Clitoria ternatea (L.) Old and new aspects, Journal of Pharmacy Research 2010, 3(11), 26102614.

12. Bakhtiar Lijon, Nigar Sultana Meghla, Eleas Jahedi, Abdur rahman, Ismail Hossain, Phytochemistry and pharmacological activities of clitoria ternatea, International Journal of Natural and Social Sciences, 2017, 4(1), pg. 7

13. Manju Lata Zingare, Prasanna Lata Zingare, Ashish Ku Dubey, Md. Aslam Ansari, Clitoria ternatea (Aparajita) : A Review of the Antioxidant, Antidiabetic and Hepatoprotective potentials, IJPBS, Vol.3. issue-1, 2013, pg 203-213.

4. Bakhtiar Lijon, Nigar Sultana Meghla, Eleas Jahedi, Abdur rahman, Ismail Hossain, Phytochemistry and pharmacological activities of clitoria ternatea, International Journal of Natural and Social Sciences, 2017, 4(1), pg. 6

15. Shyamkumar and Bhat Ishwar, Anti inflammatory, analgesic and phytochemical studies of clitorea ternatea Linn. Flower extract, International Research Journal of Pharmacy, 2012, 3(3), pg. 209

16. Birla Kshetrimayum, Medicinal plants and its therapeutic uses, A Review on Clitorea ternatea Linn. Chemistry and Pharmacology, OMICS Group eBooks, Jan. 2017, pg. 14

17. Birla Kshetrimayum, Medicinal plants and its therapeutic uses, A Review on Clitorea ternatea Linn. Chemistry and Pharmacology, OMICS Group eBooks, Jan. 2017, pg. 13 
18. Manju Lata Zingare, Prasanna Lata Zingare, Ashish Ku Dubey, Md. Aslam Ansari, Clitoria ternatea (Aparajita) : A Review of the Antioxidant, Antidiabetic and Hepatoprotective potentials, IJPBS, Vol.3. issue-1, 2013, pg 203-213.

19. Dnyaneshwar Taur, Ravindra Patil, Antihistaminic activity of Clitoria ternatea L roots, Journal of Basic and Clinical Pharmacy, Vol-002 Issue-001 February 2011 pg. 41-44.

20. Chakraborthy GS, Kumar V, Gupta S, Kumar A, Gautam N, Kumari L, Phytochemical and pharmacological aspects of clitoria ternatea - A Review, JAPSR, 1(2), pg. 7.

21. Vd. P. G. Aathavale, Drushtartha Sushruta Chintan, Vol II, Godawari publishers, first edition, Kalpsthana, ch. 2 Verse 45, 46. Pg. no. 299.

22. Vd. P. G. Aathavale, Drushtarth Sushruta Chintan, Vol II, Godawant publishers, first edition, Kalpsthana, ch. 5 Verse 17, Pg. no. 314.

23. Vd. P. G. Aathavale, Drushtartha Sushruta Chintan, Vol II, Godawari publishers, first edition, Kalpsthana, ch. 5 Verse 75, Pg. no. 319.

24. Vd. P. G. Aathavale, Drushtartha Sushruta Chintan, Vol II, Godawari publishers, first edition, Kalpsthana, ch. 5 Verse 76,77, Pg. no. 320.

25. Kaviraj Atridev gupta, Ashtanghridayam, Chaukhambha prakashan, Reprint 2007, Uttarsthan, Ch. 36, Verse 57, pg.no. 584.

26. Pa. Kashinatha shastri, Charaksamhita, part II, Chaukhambha Bharati Academy, Varanasi, Reprint 2002, Chikitsa sthana, Ch. 23, verse 195, pg.no. 660.

27. Vd. P. G. Aathavale, Drushtartha Sushruta Chintan, Vol II, Godawari publishers, firast edition, Kalpsthana, ch. 7 Verse 40 Pg. no. 328.

28. Pa. Lalchandrashastri Vaidya, Ashtangsamgraha, Shri Vaidyanath Ayurved Bhavana, first edition, Uttarsthana, Cp.46, verse 42,43, pg. no. 758.

29. Pa. Lalchandrashastri Vaidya, Ashtangsamgraha, Shri Vaidyanath Ayurved Bhavana, first edition, Uttarsthana, Cp.46, verse 55, pg. no. 759.

30. Pa. Lalchandrashastri Vaidya, Ashtangsamgraha, Shri Vaidyanath Ayurved Bhavana, first edition, Uttarsthana, Cp.44, verse 42-44, pg. no. 726.

31. Pa. Lalchandrashastri Vaidya, Ashtangsamgraha, Shri Vaidyanath Ayurved Bhavana, first edition, Uttarsthana, Cp.44, verse 61, pg. no. 728.

2. Pa. Lalchandrashastri Vaidya, Ashtangsamgraha, Shri Vaidyanath Ayurved Bhavana, first edition, Uttarsthana, Cp.44, verse 73, pg. no. 731.

33. Pa. Lalchandrashastri Vaidya, Ashtangsamgraha, Shri Vaidyanath Ayurved Bhavana, first edition, Uttarsthana, Cp.43, verse 75, pg. no. 711.

34. Pa. Kashinatha shastri, Charaksamhita, part II, Chaukhambha Bharati Academy, Varanasi, Reprint 2002, Chikitsa sthana, Ch. 23, verse 100, pg.no. 640.

35. Pa. Kashinatha shastri, Charaksamhita, part II, Chaukhambha Bharati Academy, Varanasi, Reprint 2002, Chikitsa sthana, Ch. 23, verse 210, pg.no. 662.

36. Pa. Lalchandrashastri Vaidya, Ashtangsamgraha, Shri Vaidyanath 
Ayurved Bhavana, first edition, Uttarsthana, Cp.43, verse 55, pg. no. 707.

37. Pa. Lalchandrashastri Vaidya, Ashtangsamgraha, Shri Vaidyanath Ayurved Bhavana, first edition, Uttarsthana, Cp.47, verse 41, pg. no. 776.

38. Kaviraj Atridev gupta, Ashtanghridayam, Chaukhambha prakashan, Reprint 2007, Uttarsthan, Ch. 35, Verse 45, 46, pg.no. 578.

39. Vd. P. G. Aathavale, Drushtartha Sushruta Chintan, Vol II, Godawari publishers, firast edition, Kalpsthana, ch. 6 Verse 14-27, Pg. no. 322, 323.

40. Vd. P. G. Aathavale, Drushtartha Sushruta Chintan, Vol II, Godawari publishers, firast edition, Kalpsthana, ch. 6 Verse 12, 13, Pg. no. 322.

41. Kaviraj Atridev

gupta, Ashtanghridayam, Chaukhambh prakashan, Reprint 2007, Uttarsthan Ch. 36, Verse 60, pg.no. 584.

42. Pa. Lalchandrashastri Vaidya, Ashtangsamgraha, Shri Vaidyanath Ayurved Bhavana, first edition, Uttarsthana, Cp. 40, verse 90-94, pg. no. $636,637$.
43. Pa. Lalchandrashastri Vaidya, Ashtangsamgraha, Shri Vaidyanath Ayurved Bhavana, first edition, Uttarsthana, Cp. 40, verse 105-107, pg. no. 638, 639.

44. Pa. Lalchandrashastri Vaidya, Ashtangsamgraha, Shri Vaidyanath Ayurved Bhavana, first edition, Uttarsthana, Cp. 42, verse 87-90, pg. no. $691,692$.

45. Pa. Kashinatha shastri, Charaksamhita, part II, Chaukhambha Bharati Academy, Varanasi, Reprint 2002, Chikitsa sthana, Ch. 23, verse 95, pg.no. 639.

46. Pa. Kashinatha shastri, Charaksamhita, part II, Chaukhambha Bharati Academy, Varanasi, Reprint 2002, Chikitsa sthana, Ch. 23, verse 212-214, pg.no. 662.

47. Pa. Kashinatha shastri, Charaksamhita, part II, Chaukhambha Bharati Academy, Varanasi, Reprint 2002, Chikitsa sthana, Ch. 23, verse 242-249, pg.no. 666.

48. Pa. Lalchandrashastri Vaidya, Ashtangsamgraha, Shri Vaidyanath Ayurved Bhavana, first edition, Uttarsthana, Cp. 40, verse 38, pg. no. 625.

\footnotetext{
Cite article:

A REVIEW ON APARAJITA (CLITORIA TERNATEA) WITH SPECIAL REFERENCE TO VISHA CHIKITSA

Savita B. Chougule

Ayurlog: National Journal of Research in Ayurved Science- 2018; (6)(6) : 1-9
} 